\title{
Keragaman Populasi Pohon Asam (Tamarindus indica L.) di Jalan Raya Socah-Arosbaya, Kabupaten Bangkalan dan Strategi Konservasi
}

\author{
Eko Setiawan \\ Prodi Agroteknologi, Fakultas Pertanian, Universitas Trunojoyo Madura \\ e_setiawan@trunojoyo.ac.id
}

\begin{abstract}
ABSTRAK
Pohon asam (Tamarindus indica) sangat sesuai untuk peneduh dan lanskaping karena bentuk tajuknya rindang, daunnya kecil-kecil, rantingnya kuat dan tidak mudah patah. Tujuan dari penelitian ini adalah untuk mengetahui populasi pohon asam di sepanjang Jl. Raya Socah-Arosbaya, Kabupaten Bangkalan. Survei dilaksanakan pada Juni-Agustus 2018 dengan metode purposive sampling mulai dari jalan raya Socah dengan koordinat 705'48.6"LS 11242'44.3"BT sampai Jalan

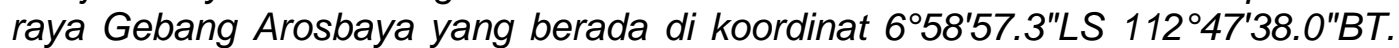
Hasil penelitian menunjukkan populasi pohon asam sepanjang Jl. Raya SocahArobaya hanya ada 102 tanaman (5.03\%) dengan indeks biodiversitas sebesar 0.1509 . Pohon asam perlu dilestarikan karena selain bernilai sejarah juga sebagai tempat endemik anggrek Vanda limbata dan kepentingan penelitan biologi di lahan kering.
\end{abstract}

Kata Kunci: Bangkalan, indeks biodiversitas, peneduh, pohon asam, Tamarindus indica

\section{Population Diversity of tamarind (Tamarindus indica L.) populations in Socah-Arosbaya Highway, Bangkalan District and Conservation Strategies}

\begin{abstract}
The tamarind tree (Tamarindus indica) is very suitable for shade and landscape because the the canopy is shady, the leaves are small, the branches are strong and not easily broken. The purpose of this study was to determine the tamarind tree population along Socah-Arosbaya highway, Bangkalan district. The survey was done in June-August 2018 with purposive sampling method, starting from Socah highway with coordinates $7^{\circ} 05^{\prime} 48.6^{\prime \prime} S 112^{\circ} 42^{\prime} 44.3^{\prime \prime} E$ to Gebang Arosbaya highway located at coordinates 6 $6^{\circ} 58^{\prime} 57.3^{\prime \prime S} 112^{\circ} 47^{\prime} 38.0^{\prime \prime} \mathrm{E}$. The results showed the tamarind tree population along Socah-Arobaya highway there are only 102 plants (5.03\%) with a diversity index was 0.1509. Tamarind trees need to be conserved because in addition to historical value as well as a place of Vanda limbata orchids and the importance of biological research on dry land.
\end{abstract}

Keywords: Bangkalan, diversity index, shade, tamarind tree, Tamarindus indica 


\section{PENDAHULUAN}

Pohon asam di Indonesia banyak ditemukan sebagai tanaman yang tumbuh di pinggir jalan mempunyai nama latin Tamarindus indica L., adalah anggota dicotyledonous (Vasantha et al., 2014) dengan famili Leguminosae (Fabaceae) (Bhadoriya et al., 2011), di Madura dikenal dengan nama acem (Soemardji, 2007). Akar tunjang yang kuat membuah pohon kokoh dan tidak mudah rebah. Kanopi pohon asam bagus untuk tujuan penahan angin karena tidak mudah patah jika terkena angin (Kidaha et al., 2017), mempunyai kanopi yang ridang sesuai untuk berteduh serta daunnya tidak mengotori jalan. Pemerintah Kolonial Belanda menanam pohon asam di setiap tepi jalan karena tanaman ini mempunyai banyak manfaat. Hampir semua jalan di kota-kota besar dan jalan yang menghubungkan kabupaten dengan kecamatan ditanami dengan tanaman yang rindang ini. "Pohon berumur" tersebut biasa ditanam di tepi jalan sebagai peneduh, dan salah satu yang terkenal adalah sepanjang jalan raya Daendels (dari Anyer hingga Panarukan), sedangkan di Madura salah satunya bisa ditemukan di Kabupaten Bangkalan. Tanaman pohon asam ini tidak memerlukan pemeliharaan khusus dan tahan terhadap kondisi kering (Ranaivoson et al., 2015), sehingga disebut die hard. Pohon asam mampu hidup lama bahkan antara 60-200 tahun (Vasantha et al., 2014).

Populasi pohon asam jawa di pingir jalan raya Kabupaten Bangkalan terus menurun, oleh karena itu, keberadaan hidupnya hanya dapat dijamin jika intervensi konservasi dilakukan. Pengetahuan terperinci tentang struktur populasi asam di habitatnya yang disepanjang jalan raya Socah-Gebang Arosbaya diperlukan untuk membantu menjelaskan kebutuhan dan strategi yang diperlukan untuk konservasi spesies jangka panjang. Penelitian ini difokuskan pada keragaman spesies yang ada di tepi jalan raya untuk peneduh, tidak meneliti aspek pemanfaatan maupun produksi pohon asam.

\section{METODE PENELITIAN}

Penelitian ini dibatasi pada wilayah tepi jalan sebelah kiri dan kanan antara jalan raya yang menghubungkan Socah sampai Gebang Arosbaya yang terdapat pohon asam, sepanjang $16 \mathrm{Km}$ (Gambar 1). Survei dilakukan di bagian Barat Kabupaten Bangkalan pada Juni-

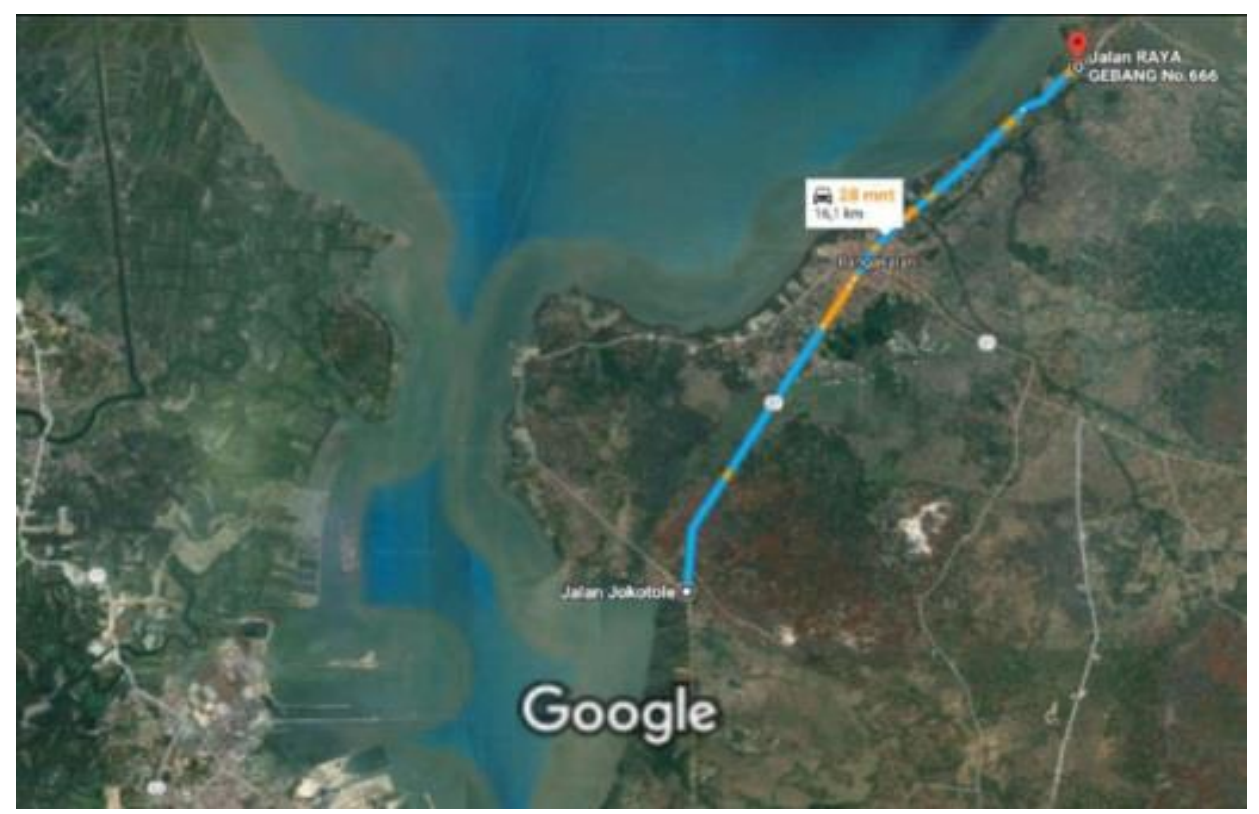

Gambar 1. Peta sisi Barat Kabupaten Bangkalan. Garis warna biru adalah lokasi survei jalan raya yang menghubungkan Socah-Gebang Arosbaya 
Agustus 2018 dengan metode purposive sampling mulai dari jalan raya Socah dengan koordinat $\quad 7^{\circ} 05^{\prime} 48.6 " \mathrm{LS}$ $112^{\circ} 42^{\prime} 44.3^{\prime \prime B T}$ sampai Jalan raya Gebang Arosbaya yang berada di koordinat $6^{\circ} 58^{\prime} 57.3^{\prime \prime L S ~} 112^{\circ} 47^{\prime} 38.0^{\prime \prime B T}$. Penelitian ini menggunakan metode penelitian kuantitatif. Metode tersebut dapat diperoleh dari pengamatan, pengambilan foto dan dengan menghitung indeks biodiversitas dengan menggunakan rumus Shanoon menyatakan sebagai berikut:

$\mathrm{H}^{\prime}=-\sum(\mathrm{ni} / \mathrm{N} \ln \mathrm{ni} / \mathrm{N})$

Di mana :

$H^{\prime}$ : Indeks keanekaragaman spe-sies

ni : Jumlah individu spesies ke-i

$\mathrm{N}$ : Jumlah total individu.

Keterangan:

$H^{\prime}<1$ :Keanekaragaman rendah dan keadaan komunitas rendah

$1<H^{\prime}<3$ :Keanekaragaman sedang dan keadaan sedang

$H^{\prime}>3$ :Keanekaragaman tinggi dan keadaan tinggi.

Dimana H'= nilai indeks Shanoon, jika komunitas hanya memiliki 1 species, maka $H^{\prime}=0$. Semakin tinggi nilai $H^{\prime}$ mengindikasikan semakin tinggi jumlah species dan semakin tinggi kelimpahan relatifnya. Nilai indeks Shannon biasanya berkisar antara 1.5 - 3.5 dan jarang mencapai 4.5 (Nyadoi et al., 2009; Setiawan, 2016)

\section{HASIL DAN PEMBAHASAN}

Pohon asam bersifat evergreen (selalu hijau, karena tidak mengalami masa gugur daun) cocok digunakan sebagai elemen landscaping dan perawakan yang besar sangat baik untuk peneduh di tepi jalan raya (Kidaha et al., 2017). Tinggi pohon bisa mencapai \pm 30 $\mathrm{m}$ dan diameter batang di pangkalnya melebar hingga $2 \mathrm{~m}$ (Gambar 2). Ukuran diameter batang pohon asam yang besar bisa disebabkan beberapa faktor diantaranya toleransi terhadap cahaya, bentuk pertumbuhan, iklim, pemanfaatan hasil tanaman dan strategi bertahan tanaman (A. B. Fandohan et al., 2010). Kanopi pohonnya rindang dan lebat, melebar dan membulat, ditanam berjajar di tepi jalan akan membuat nyaman orang yang berteduh atau berjalan kaki di bawahnya (Gambar 2). Kulit batang berwarna coklat keabu-abuan, kasar dan memecah, beralur-alur vertikal. Jumlah pohon asam Jawa yang berada di tepi jalan Kamal menuju kota Bangkalan jumlahnya tinggal sedikit, sementara orang tidak berkeinginan menanam tanaman baru. Keanggunan pohon asam yang berjejer di tepi jalan hanya bisa dilihat sesaat sebelum memasuki Kota Bangkalan, yaitu daerah Klobungan dan di Jalan Gebang Arosbaya. Sepanjang jalan terlihat hijau, udara terasa sejuk dan beberapa burung bersarang di rantingnya.

$\begin{array}{lllr}\text { Setiap } & 100 & \mathrm{~g} \text { buah } & \text { asam } \\ \text { mengandung } & \text { kalori } & \text { sebesar } & 239 \\ \text { kal, } \square \text { protein } & 2.8 & \text { g, } \square \text { lemak } & 0.6\end{array}$ g, $\square$ karbohidrat $62.5 \mathrm{~g}$, $\square$ kalsium 74 mg, $\square$ phosphorus $113 \mathrm{mg}, \square$ zat besi 2.8 $\mathrm{mg}$, $\square$ vitamin A $30 \mathrm{IU}, \square$ Thiamin 0.428 $\mathrm{mg}, \square$ dan vitamin C $3.5 \mathrm{mg}$ (Kuru, 2014). Buah asam banyak dimanfaatkan sebagai bumbu masakan, minuman, bahan sirup, dan obat tradisional. Buah asam Jawa banyak digunakan untuk berbagai macam obat tradisional seperti penurun panas, masalah pernafasan, diare, disentri, dan malaria (Kuru, 2014). Minuman tradisional juga terasa segar bila dicampur dengan asam. Ranaivoson et al. (2015), minuman asam mempunyai sudah diproduksi oleh perusahaan di dalam negeri dalam kemasan modern; aroma dan rasanya yang menyegarkan memberikan selera tersendiri bagi konsumen penikmatnya.

Kriteria tentang jenis pohon yang dapat dijadikan sebagai pohon peneduh diantaranya adalah: menghasilkan oksigen yang memadai, pohon rindang sehingga membuat teduh/sejuk, menghasilkan buah sehingga mengundang burung, pohon menghasilkan bunga sehingga membuat keindahan, pohon tidak memiliki akar yang besar dan cepat tumbuh agar tidak merusak konstruksi jalan, mempunyai akar yang dapat bertahan terhadap kerusakan yang disebabkan oleh getaran lalu lintas, pohon harus memiliki cabang dan ranting yang kuat dan tidak mudah tumbang, tidak memiliki buah 
yang terlampau besar agar tidak membahayakan pengguna jalan, dan terakhir sebaiknya dipilih tanaman yang mendatangkan keuntungan. Beberapa kriteria sebagai tersebut di atas ada pada pohon asam (Tamarindus indica) sehingga cocok ditanam di pinggir jalan sebagai tanaman peneduh, karena mempunyai daun yang sangat lebat dan rimbun.

Tamarindus indica sesuai dibudidayakan di daerah tropis, tanaman ini bisa hidup di tempat yang suhu udaranya sekitar $45 \quad{ }^{\circ} \mathrm{C}$ dan perawatannya tidak terlalu rumit. Pohon asam termasuk jenis tanaman yang memiliki akar yang bisa mencapai tanah cukup dalam, tahan terhadap kekeringan dan angin kencang, dan menghasilkan buah yang banyak jika hidupnya di daerah dengan periode kering yang cukup panjang (Divakara, 2008). Pohon asam berumur tahunan, dikategorikan tumbuhan dikotil dengan ciri-ciri mempunyai daun lebat kecil berumpun, potensi berbatang besar, batang tanaman keras, buah polong
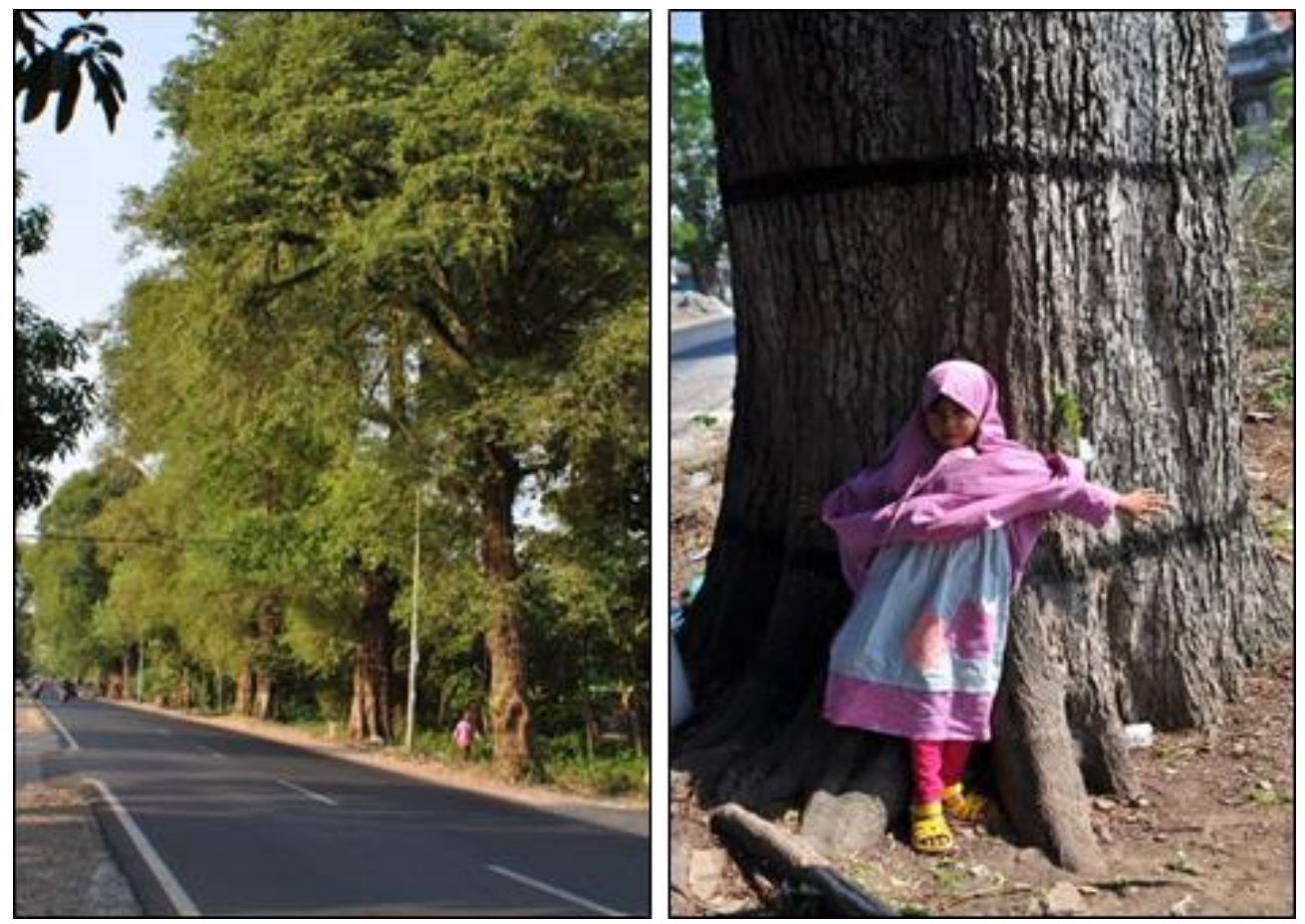

Gambar 2. Deretan pohon asam disebelah Timur jalan di Socah, terilihat seorang ibu sedang berjalan di bawah rindangnya kanopi pohon asam (kiri), dan batang bawah pohon asam berukuran besar yang melebihi bentangan tangan seorang anak (kanan). 
Sejak jaman penjajahan sampai dengan kemerdekaan sudah lebih dari 73 tahun, pohon asam ini berhasil menaungi jalan yang menghubungkan kecamatan Socah dengan Arosbaya. Tabel 1 menginformasikan saat ini hanya tinggal 102 pohon asam yang tersebar di kanan maupun kiri jalan sejauh $16 \mathrm{Km}$ dengan rincian di wilayah Socah terdapat 52 pohon dan sisanya sebanyak 50 pohon berada di wilayah Arosbaya.

Dari Tabel 2 diperoleh informasi bahwa sepanjang lokasi penelitian terdapat 24 jenis tanaman dengan total 2028 pohon yang digunakan sebagai peneduh di tepi jalan. Pohon angsana (Pterocarpus indicus) merupakan tanaman yang paling dominan digunakan sebagai pilihan peneduh tepi jalan sebanyak $38.91 \%$. Pohon asam (Tamarindus indica) merupakan pohon kelima terbanyak setelah pohon angsana (Pterocarpus indicus), mahoni (Swietenia mahagoni), trembesi (Samanea saman), dan flamboyan (Delonix regia). Jumlah pohon asam di lokasi penelitian saat ini hanya sebanyak $5.03 \%$ dari keseluruhan pohon. Nilai indeks biodiversitas dari pohon asam hanya sebesar 0.1509 . Pohon peneduh jalan yang berada di sepanjang kecamatan Bangkalan Kota Bangkalan tidak ditemukan satupun pohon asam yang tumbuh. Keberadaan pohon asam sudah digeser oleh pohon angsana (Pterocarpus indicus) dan gelodok tiang (Polyalthia longifolia). Di wilayah kota Bangkalan ditemukan sebanyak 63 tanaman Spathodea campanulata yang menghasilkan bunga berwarna ungu. Pohon asam hanya tersisa di daerah Socah sampai Klobungan sebelum masuk wilayah kota serta di daerah Arosbaya. Di sebelah Utara kota
Bangkalan menuju Arosbaya pohon peneduh lebih didominasi oleh pohon mahoni (Swietenia mahagoni). Sementara pohon flamboyan (Delonix regia) banyak ditemukan di tepi jalan sebelah Timur arah Socah-Bangkalan.

Dari 102 pohon yang tersisa, beberapa pohon asam kondisi batangnya rusak seperti bekas dibakar dibagian pangkalnya (Gambar 4) sehingga bagian tengah batang menjadi keropos dan berlubang. Beberapa pohon mengalami kerusakan akibat dipotong sebagian atau ditebang semata-mata hanya karena orang tertarik keunikan dari kayu yang begitu baik kualitasnya untuk dijadikan bonsai (Gambar 3). Populasi pohon asam yang ada di Bangkalan menjadi berkurang. Dari semua kegunaan pohon asam yang disebutkan di atas, kayu dan pohonnya paling diminati orang karena kualitas kayunya bagus (Farooq and Farooq, 2003), di Bangkalan banyak orang mengambil bagian pohon asam untuk kebutuhan bonsai atau tanaman hias. Pada Gambar 3 merupakan hasil aktivitas mencangkok pohon asam untuk dibuat bonsai yang selanjutnya diperjualbelikan. Keindahan bonsai pohon asam membuat orang berfikir singkat bagaimana mendapatkan tanaman secara cepat, karena pohon asam memerlukan waktu bertahu-tahun untuk besar. Kerusakan juga disebabkan oleh kegiatan membakar sampah di pokok batang yang menyebabkan bagian tengah pohon menjadi berlubang. Kerusakan juga terjadi karena pohon terlalu sering dipaku untuk menempel iklan atau poster sehingga sebagian pohon menjadi rusak, kering, dan busuk (Gambar 4).

Tabel 1. Populasi pohon asam antara Socah sampai Gebang Arosbaya

\begin{tabular}{lccc}
\hline \multirow{2}{*}{ Rute Jalan } & \multicolumn{2}{c}{ Jumlah Pohon Asam di tepi jalan } & \multirow{2}{*}{ Jumlah } \\
\cline { 2 - 3 } & sebelah Barat & sebelah Timur & \\
\hline Jl. Raya Socah-Bangkalan & 36 & 16 & 52 \\
Jl. Raya Bangkalan-Gebang & 13 & 37 & 50 \\
Arosbaya & & & 50 \\
\hline
\end{tabular}


Tabel 2. Keanekaragaman Tanaman Peneduh di tepi jalan antara Socah-Gebang Arosbaya, Bangkalan

\begin{tabular}{|c|c|c|c|c|c|}
\hline No & Nama ilmiah & Nama daerah & $\begin{array}{l}\text { Jumlah Total } \\
\text { Tanaman }\end{array}$ & $\begin{array}{c}\text { Persen } \\
\text { Tanaman (\%) }\end{array}$ & $\begin{array}{c}\text { Indeks } \\
\text { Biodiversitas }\end{array}$ \\
\hline 1 & Pterocarpus indicus & Angsana & 789 & 38.91 & 0.3672 \\
\hline 2 & Swietenia mahagoni & Mahoni & 388 & 19.13 & 0.3170 \\
\hline 3 & Samanea saman & Trembesi & 170 & 8.38 & 0.2084 \\
\hline 4 & Delonix regia & Flamboyan & 133 & 6.56 & 0.1792 \\
\hline 5 & Tamarindus indica & Asam Jawa & 102 & 5.03 & 0.1509 \\
\hline 6 & Mangifera indica & Mangga & 70 & 3.45 & 0.1166 \\
\hline 7 & Spathodea campanulata & Kiacret & 63 & 3.11 & 0.1082 \\
\hline 8 & Acacia alba & Akasia & 55 & 2.71 & 0.0982 \\
\hline 9 & Muntingia calabura & Kersen & 47 & 2.32 & 0.0876 \\
\hline 10 & Canarium ovatum & Kenari & 40 & 1.97 & 0.0777 \\
\hline 11 & Polyalthia longifolia & Glodok tiang & 39 & 1.92 & 0.0763 \\
\hline 12 & Langerstroemia speciosa & Bungur & 16 & 0.79 & 0.0384 \\
\hline 13 & Ficus elastica & Beringin variegata & 15 & 0.74 & 0.0364 \\
\hline 14 & Hibiscus tiliaceus & Waru & 14 & 0.69 & 0.0345 \\
\hline 15 & Terminalia catappa & Ketapang & 14 & 0.69 & 0.0345 \\
\hline 16 & Azadirachta indica & Mimba & 14 & 0.69 & 0.0345 \\
\hline 17 & Ceiba petandra & Kapuk Randu & 12 & 0.59 & 0.0305 \\
\hline 18 & Filicium decipiens & Kiara payung & 10 & 0.49 & 0.0263 \\
\hline 19 & Tabebuia cassinoides & Tabebuya & 10 & 0.49 & 0.0263 \\
\hline 20 & Arecaceae sp & Palem & 9 & 0.44 & 0.0241 \\
\hline 21 & Lannea coromandelica & Kayu Jaran & 8 & 0.39 & 0.0219 \\
\hline 22 & Ziziphus mauritiana & Bidara & 6 & 0.30 & 0.0173 \\
\hline 23 & Artocarpus heterophyllus & Nangka & 3 & 0.15 & 0.0097 \\
\hline \multirow[t]{2}{*}{24} & Tectona grandis & Jati & 1 & 0.05 & 0.0038 \\
\hline & Jumlah & & 2028 & 100 & 2.1254 \\
\hline
\end{tabular}
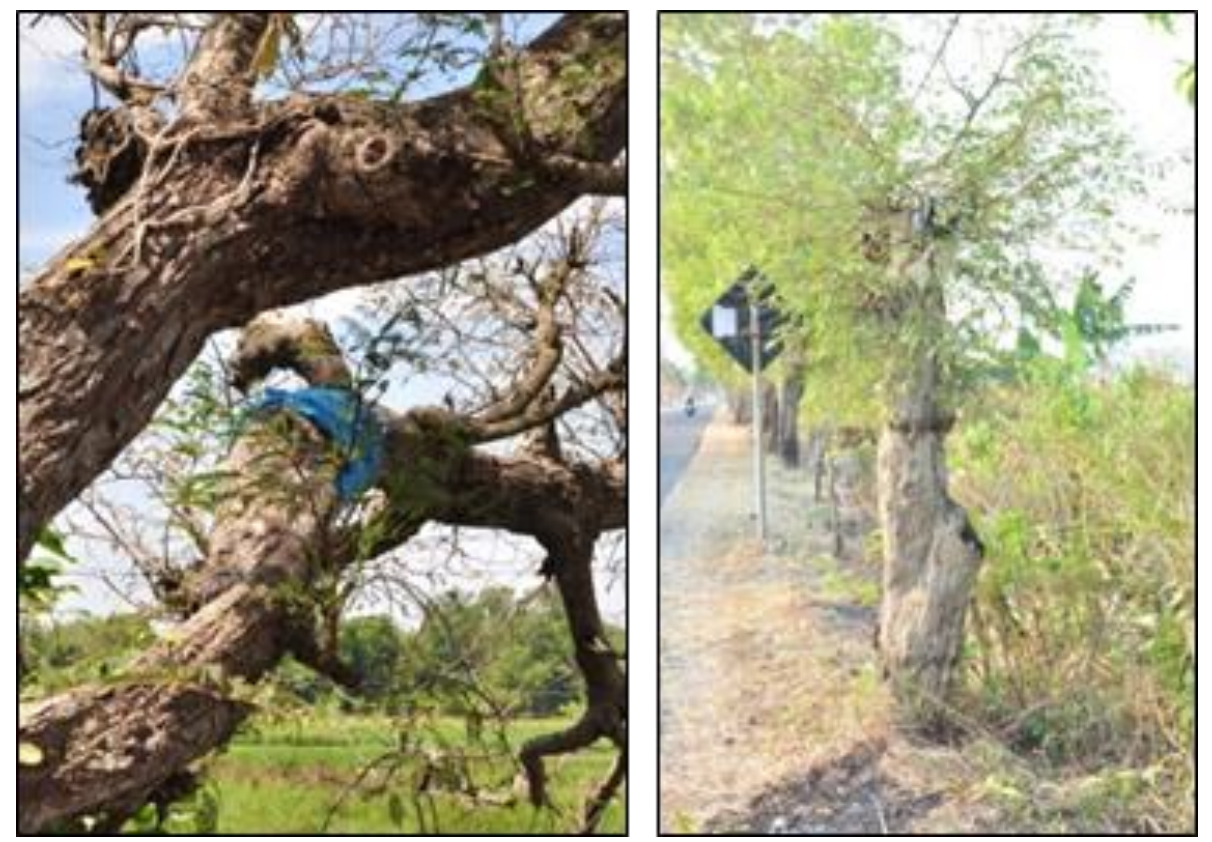

Gambar 3. Kerusakan pohon asam untuk pembuatan hias bonsai, batang pohon asam dicangkok (kiri), dan pohon asam yang terpotong oleh aktivitas pembuatan bonsai sudah bertunas dan ranting pohon asam yang baru berkembang sudah dilakukan pencangkokan kedua kali untuk bonsai (kanan).

Dari penelitian ini sangat jelas Dari penelitian ini sangat jelas bahwa mempertahankan keberadaan pohon asam di Kabupaten Bangkalan mendesak untuk dilakukan, karena aktivitas manusia yang mengeksploitasi pohon asam bisa menyebabkan jumlah pohon asam berkurang ( Fandohan et al., 

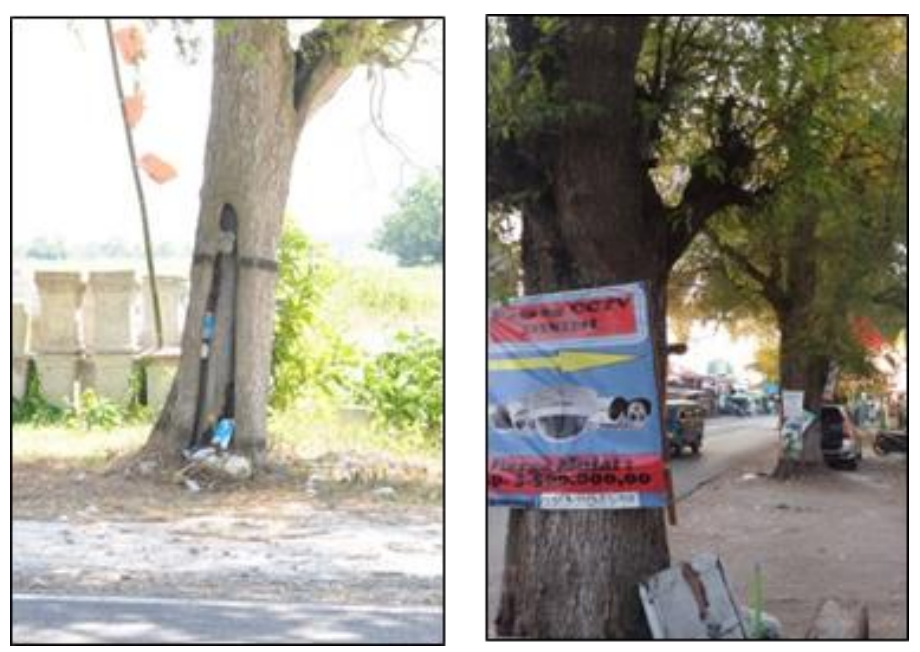

Gambar 4. Kerusakan pohon asam karena aktivitas pembakaran sampah di pangkal batang pohon asam yang membuat batang berlubang (kiri), dan pohon asam yang dipaku untuk menempel iklan atau papan reklame membuat batang menjadi rusak dan bisa menyebabkan roboh atau patah (kanan).

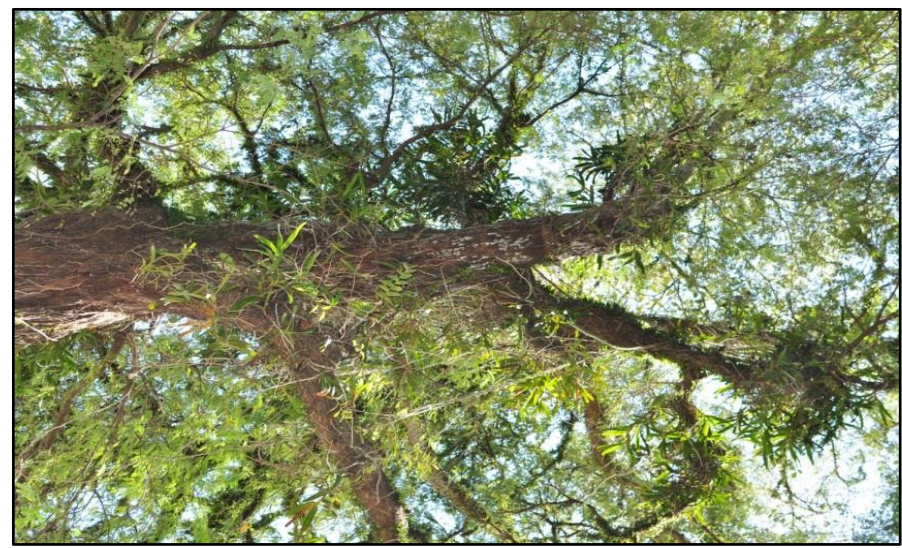

Gambar 5. Pohon asam sebagai tempat tumbuh dan inang dari angrek Vanda limbata

2010; Fandohan et al., 2011). Dari penelitian ini diketahui pohon asam yang berjumlah 102 batang, beberapa diantaranya menjadi tempat inang dari anggrek Vanda limbata yang hidup secara alami sejak beberapa puluh tahun yang lalu (Gambar 5). Keberadaan anggrek Vanda limbata merupakan kejadian yang cukup langka. Dari pengamatan penulis, pohon asam di luar Bangkalan seperti di wilayah Kediri dan Blitar hampir tidak ada pohon asam yang tumbuh di tepi jalan menjadi inang dari anggrek Vanda limbata. Pada pohon asam yang besar dan berumur puluhan tahun bisa terdapat lebih dari ratusan tanaman epifit anggrek Vanda limbata (Gambar 5).
Pelestarian pohon asam selain menjaga keberadaan pohon warisan kolonial yang menjadi saksi perjalanan sejarah juga akan melestarikan sejumlah anggrek Vanda limbata yang mulai langka. Penebangan atau perusakan pohon asam di Bangkalan berarti juga perusakan habitat asli dari anggrek Vanda limbata. Seperti kita ketahui bahwa penanaman anggrek dengan menempelkan ke batang-batang pohon peneduh di tepi jalan yang dilakukan secara masif oleh pemerintah kota Surabaya menghabiskan biaya yang tinggi dari sisi pengadaan bibit serta membutuhkan perawatan yang intensif. Usaha menanam anggrek oleh beberapa peneliti di Kampus Universitas Jember 
tingkat keberhasilannya rendah karena keterbatasan bibit dan kesulitan dalam perawatan. Keberadaan anggrek Vanda limbata yang berada di pohon asam secara alami bisa menjadi identitas dari Kabupaten Bangkalan. Pelestarian pohon asam dan anggrek Vanda limbata bisa dijadikan sebagai bahan kajian lebih lanjut oleh peneliti Universitas Trunojoyo Madura tentang kehidupan mikroorganisme yang berasosiasi di kulit pohon asam tersebut. Asosiasi bakteri dan jamur mikoriza yang ada di pohon asam bisa mengatasi stres abiotik (Sudheep and Sridhar, 2012). Ini merupakan kekayaan biologi dari lahan kering, dilaporkan bahwa pada tanaman anggrek bisa dikembangkan dengan penambahan mikorisa untuk menyerupai kondisi di alam (Liu et al., 2010). Bunga anggrek Vanda limbata mempunyai bau yang harum dan warna coklat kekuningan yang indah. Pelestarian anggrek Vanda limbata bisa dimanfaatkan sebagai induk untuk pengembangan anggrek dalam kegiatan persilangan. Dinas Pertanian Kabupaten Bangkalan perlu bekerjasama dengan pihak terkait dalam menertibkan kegiatan

\section{DAFTAR PUSTAKA}

Bhadoriya, S.S., A. Ganeshpurkar, J. Narwaria, G. Rai, A.P. Jain. 2011. Tamarindus indica: extent of explored potential. Pharmacogn. Rev. 5(9): 73-82.

Bourou, S., C. Bowe, M. Diouf, P. Van Damme. 2012. Ecological and human impacts on stand density and distribution of tamarind (Tamarindus indica L.) in Senegal. Afr. J. Ecol. 1-13.

Divakara, B.N. 2008. Variation and character association for various pod traits in Tamarindus indica $\mathrm{L}$. Indian For. 687-698.

Ebifa-Othieno, E., A. Mugisha, P. Nyeko, J.D. Kabasa. 2017 Knowledge, attitudes and practices in tamarind (Tamarindus indica L) use and conservation in Eastern Uganda. eksploitasi pohon asam agar tidak merusak keberadaan pohon asam dan anggrek Vanda limbata. Perlu difikirkan tentang pembibitan pohon asam, peremajaan, dan penanaman pohon asam yang baru di wilayah Kabupaten Bangkalan. Usaha pelestarian pohon asam memerlukan pengetahuan, etika dan praktik (Ebifa-Othieno et al., 2017). Keberadaan pohon asam yang berkurang jumlahnya juga dilaporkan terjadi di Senegal karena kegiatan manusia (Bourou et al., 2012)

\section{SIMPULAN}

Jumlah pohon asam di Jl. Raya Socah-Arobaya saat ini hanya tinggal 102 tanaman atau sebesar $5.03 \%$ dari total tanaman peneduh yang ditanam di tepi jalan. Indeks biodiversitas pohon asam hanya sebesar 0.1509 yang berarti keadaan populasinya sangat rendah. Perlu pelestarian pohon asam karena selain bernilai sejarah juga sebagai tempat endemik anggrek Vanda limbata untuk kepentingan penelitan biologi di lahan kering.

\section{J. Ethnobiol. Ethnomed. 13(5): 1-13.}

Fandohan, A.B., A.E. Assogbadjo, R.L.G. Kakai, B.S. Sinsin, P. Van Damme. 2010. Impact of habitat type on the conservation status of tamarind (Tamarindus indica L.) populations in the $\mathrm{W}$ National Park of Benin. Fruits 65(1): 1119.

Fandohan, B., A.E. Assogbadjo, R.G. Kakaï, B. Sinsin. 2011. Geographical distribution, tree density and fruit production of Tamarindus indica L. (Fabaceae) across three ecological regions in Benin. Fruits 66(2): 65-78.

Farooq, S.A., T.T. Farooq. 2003. Rapid clonal propagation of Tamarindus indica L. using explants from adult trees. Pakistan J. Biol. Sci. 6(18): 1591-1592. 
Kidaha, M.L., F.K. Rimberia, R.K. Wekesa, W. Karuki. 2017. Evaluation of tamarind (Tamarindus indica) utilization and production in eastern parts of Kenya. Asian Res. J. Agric. 6(2): 1-7.

Koffi, K.E., N. Diarrassouba. 2009. Socio-economic values of tamarind (Tamarindus indica L.) and nereid (Parkia biglobosa Benth) resources in Côte d' Ivoire. Acta Hort. 806: 533-538.

Kuru, P. 2014. Tamarindus indica and its health related effects. Asian Pac. J. Trop. Biomed. 4(9): 676681.

Liu, H., Y. Luo, H. Liu. 2010. Studies of mycorrhizal fungi of Chinese orchids and their role in orchid conservation in China - a review. Bot. Rev. 76: 241-262.

Nyadoi, P., P. Okori, J.B.L. Okullo, J. Obua, K. Burg, M. Nasoro, R. Jamnadass. 2009. Tamarinds' (Tamarindus indica L.) niche tree species diversity characterisation reveals conservation needs and strategies. Int. J. Biodivers. Conserv. 1(4): 151-176.

Rajput, K.S., K.S. Rao. 2001. Cambial activity and development of xylem in Tamarindus indica $\mathrm{L}$. growing in different forests of Gujarat state. Acta Bot. Hung. 43(3-4): 379-390.
Ranaivoson, T., K. Brinkmann, B.

Rakouth, A. Buerkert. 2015.

Distribution, biomass and local importance of tamarind trees in south-western Madagascar.

Glob. Ecol. Conserv. 4: 14-25.

Setiawan, E. 2016. Pemanfaatan pekarangan dengan penanaman tanaman obat dan pangan untuk meningkatkan ekonomi rumah tangga petani di Sampang. In Prosiding Seminar Nasional Agribisnis dan Pengembangan Ekonomi Perdesaan III (pp. 111117).

Soemardji, A.A. 2007. Tamarindus indica L. or "Asam Jawa": the sour but sweet and useful. Visit. Profr. Inst. Nat. Med. Univ. Toyama Japan. (May): 1-20.

Sudheep, N.M., K.R. Sridhar. 2012. Non-mycorrhizal fungal endophytes in two orchids of Kaiga forest (Western Ghats), India. J. For. Res. 23(3): 453460.

Vasantha, P.T., R.C. Vijendrakumar, T.R. Guruprasad, M. Mahadevamma, K.V. Santhosh. 2014. Studies on effect of growth regulators and biofertilizers on seed germination and seedling growth of tamarind (Tamarindus indica L.). Plant Arch. 14(1): 155-160. 